\title{
THE FIRST ADAM-SECOND ADAM TYPOLOGY IN JOHN CHRYSOSTOM AND CYRIL OF ALEXANDRIA
}

\author{
ASHISH J. NAIDU* \\ Talbot School of Theology, Biola University
}

\begin{abstract}
Patristic scholars have commented on the early church's common practice of drawing catechetical instructions from the creation account in Genesis. One of the recurring motifs in such discussions is the fathers' use of the Adam-Christ typology with its soteriological and sacramental implications. The present study briefly explores this theme in John Chrysostom and Cyril of Alexandria with particular reference to the baptism of Jesus and the theological challenge it posed to the early church: Did Jesus the Lord receive the Spirit at his baptism? Why did he need to be baptized? What is the relationship between the baptism of Jesus and Christian baptism? Both Cyril and Chrysostom make insightful use of the Adamic typology in this context as they discuss how Christ's work restores fallen humanity from corruption and death that followed Adam's sin. First, the study examines how the aforementioned fathers from two distinct traditions view the baptism of Jesus in the recovery of God's grace that was lost in Adam's fall. Second, the study will demonstrate that both Chrysostom and Cyril had much in common in their understanding of the transforming grace and work of the Spirit in refashioning the believer into a new creation at baptism. And third, it will be shown that there was a consensus on soteriological and sacramental perspectives among the Alexandrians and the Antiochenes.
\end{abstract}

KEY WORDS: John Chrysostom, Cyril of Alexandria, Patristic Typology, Christology, Soteriology

\section{Introduction}

Robert Wilken has drawn attention to the fact that the narrative account of the baptism of Jesus posed a challenge to the early church (Wilken, 1966: 146f). ${ }^{1}$ The conundrum of how is it that Jesus the Lord can receive the Spirit was a difficult one to get around, and needed to be answered satisfactorily. If Christ received the Spirit, does it mean that the he was inferior to the Father and therefore needed to be sanctified (see also Wilken, 1971: 93-142)? Reviewing Cyril's interpretation of John 1:32-33, Wilken observes that Cyril broached this theologically delicate issue by employing the Adam-Christ typology. Cyril maintained that Christ was both

* ASHISH J. NAIDU (PhD 2006, University of Aberdeen) is Associate Professor of Theology at Talbot School of Theology, Biola University in La Mirada, California, United States of America. Email: ashish.naidu@biola.edu

1 An earlier version of this paper was presented at the 2013 Annual Meeting of the Evangelical Theological Society in Baltimore, Maryland. For a detailed treatment of this topic, see Transformed in Christ: Christology and the Christian Life in John Chrysostom (Naidu, 2012: 107-117). 
one with the Father and yet true man. It was as man, Cyril argued, that Christ was able to receive the Spirit at his baptism. The main point of Cyril's argument is that the first Adam did not preserve the grace that was given to him by God. Therefore God the Father sent the second Adam, his own Son, in the likeness of man in every way-except without sin. Just as through the disobedience of the first Adam humanity was subject to divine wrath, the obedience of the second Adam reversed the curse. After the incarnation Christ, as the one who knew no sin, received the Spirit from the Father, thus restoring to human nature the grace that had been lost in the Fall. The reception of the Spirit by the second Adam therefore transforms and renews humanity, providing a new beginning. Cyril remarks:

But when the Word of God became Man, He received the Spirit from the Father as one of us (not receiving ought for Himself individually, for He was the Giver of the Spirit); but that He Who knew no sin, might, by receiving It as Man, preserve It to our nature, and might again root in us the grace which had left us. For this reason, I deem, it was that the holy Baptist profitably added, I saw the Spirit descending from Heaven, and It abode upon Him. For It had fled from us by reason of sin, but He Who knew no sin, became as one of us, that the Spirit might be accustomed to abide in us, having no occasion of departure or withdrawal in Him (1872: 1.184).

Contra Wilken, Welch has noted that Cyril's usage of the Adamic typology had a christological rationale: Cyril employed the seemingly paradoxical Adamic typology mainly to insist on the historical unity of the one Christ. The reception of the Spirit by Christ, Welch adds, is closely related to Cyril's emphasis on the kenosis, a theme that he invokes four times in interpretation of this passage (John 1:32-33). He maintains that Cyril was keen on showing that the Son who emptied himself is the selfsame second Adam who receives the Spirit not because he was sinful, but because he was in the 'condition' of sinful flesh. He concludes that Cyril's kenotic language and use of Adamic typology influence one another in the sense that kenosis is used to explain the historical events in the life of Christ, the second Adam. Conversely, the second Adam, who in the condition of fallen humanity needs the Spirit, is always spoken of as one and the same Christ (Welch, 1994: 66-67).

\section{John Chrysostom on Baptism of Jesus}

Chrysostom deals with the topic of the baptism of Jesus (as mentioned in Matthew 3:13-17), specifically in his twelfth homily on the Gospel of Matthew (1862c: 201208). Chrysostom's interpretation of the baptism of Jesus has soteriological overtones akin to Cyril's view. Both stress the incarnational aspects of Christ the eternal Son in regard to his baptism: Cyril employs Adamic typology and kenotic language to explain the reception of the Spirit, while Chrysostom highlights the condescension of Christ in the incarnation and his willingness to be baptized in fulfillment of the law for the redemption of humanity. Without specifically deploying a typology, Chrysostom also makes reference to the transgression of Adam and 
Christ's reversal thereof. The first Adam incurred through his disobedience the wrath of God; the second Adam delivered humanity from its curse through his obedience. Adam had paradise for his share and lost it through sin, but Christ has now made the baptized joint heirs with him, restoring the possibility of that privilege once again. ${ }^{2}$

Whereas Cyril highlights the reception of the Spirit by Christ, Chrysostom focuses on the act of baptism by underscoring Christ's claim that he did so to fulfill the law of God at all points. For Cyril, Christ as man received the Spirit to refashion humanity; for Chrysostom, Christ as man had to fulfill the law and be baptized. The main difference between Cyril and Chrysostom's interpretation is that Cyril acknowledges and explains why Christ 'received' the Spirit at his baptism, whereas Chrysostom views the descent of the Spirit as an announcement and a witness to his identity and not as a 'reception'. Chrysostom's initial focus is directed to the paradox of the eternal Son who humbles himself and submits to baptism. He observes:

With the servants the Lord, with the criminals, the Judge, comes to be baptized. But do not be troubled; for in these humiliations His exaltation does most shine forth. For He who vouchsafed to be borne so long in a Virgin's womb, and from there to take our nature, and to suffer all the rest which He suffered; why do you marvel if He vouchsafed to be baptized, and to come with the rest to His servant. For the amazement lay in that one thing, that being God, He would be made Man; but the rest after this all follows in course of reason (1862c: 202). ${ }^{3}$

Chrysostom views the obedience of Christ as being central to his mission of fulfilling the law at all points and dismissing the condemnation that held sway over humanity. The judge of all sinners himself condescended to be baptized and thereby secured a pardon for all. Christ was baptized not because he needed to receive the Spirit as man, but to reverse the curse of sin by being obedient to the law. Chrysostom uses the title 'Judge' twice in this homily to emphasize the divinity of Christ and to dispel the idea that he was baptized for the remission of sins, since he himself will judge all sinners. Christ satisfied the law of God at all points by fulfilling the commandments; thus he has done away with the curse of the transgression. The obedient Son overruled the curse written against humanity; this was the main purpose of the incarnation (Chrysostom, 1862c: 203-205). Moreover, Chrysostom observes that the reason the heavens opened and the Spir-

'For if he who had paradise for his portion, for one disobedience underwent such dreadful things after his honor; we, who have received Heaven, and are become joint heirs with the Only Begotten, what excuse shall we have, for running to the serpent after the dove' (Chrysostom, 1862c: 207)?

3 English translations of Chrysostom's commentaries are available in volumes 9-14 (Chrysostom, 1975); volume 33 (Chrysostom, 1957); and volume 41 (Chrysostom, 1960).

PERICHORESIS 12.2 (2014) 
it descended in the likeness of a dove along with the voice, was to "proclaim the dignity of the Only Begotten' and to show us that the Spirit likewise comes to those who are baptized. Chrysostom does not employ language suggesting any 'reception' of the Spirit by Christ. For him, the descent of the Spirit in the form of a dove served only to point out the one whom the voice called 'my beloved Son' (Chrysostom, 1862c: 203-5).

Chrysostom affirms that the Holy Spirit comes to the believer at baptism just like He did at Christ's baptism. The difference being that at the baptism of Christ the Spirit descended to point out the Savior; at the baptism of the Christian the Spirit descends to convey adoption into the family of God-'the greatest mark of dignity'. The Spirit's action here causes us to become the 'sons of God' (Chrysostom, 1862c: 205-206; cf. 1862a: 363-372). So Chrysostom's understanding of the baptism of Christ has both soteriological and sacramental implications for the Christian. The Son of God condescended to be baptized as part of his redeeming mission, and made us worthy to receive the grace of the Spirit, which renews and refashions us to become like Christ. Here soteriological and sacramental dimensions of the baptism of Christ are inseparably connected. The work of the Holy Spirit is highlighted in the process of adoption, whereby the Christian is conformed to the likeness of Christ at baptism (Chrysostom, 1862c: 205-206). Commenting on John 1:12_'To as many as received Him he gave them power of becoming sons of God'-Chrysostom asserts:

Such is the power of faith in Him; such the greatness of His grace. And even as the element of fire, having come in contact with ore from mines, forthwith makes the ore true gold; so also, and even more, does baptism make those who have been washed in it golden instead of earthy, since the Spirit at that time falls like fire on our souls, both

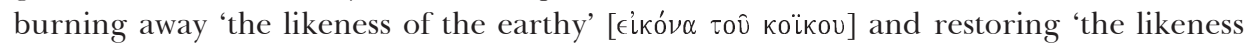

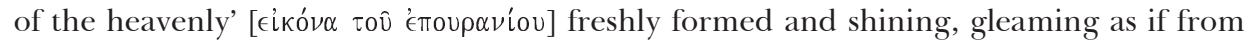
the smelting furnace (1862d: 76).

Through the mediation of the Holy Spirit, Christ makes us the 'sons of God' by replacing the 'likeness of the earthy' with the 'likeness of the heavenly' (Chrysostom, 1862d: 424f). Unlike the baptism of John, which does not possess the power either to remit sin or renew the believer, the grace of Christ has inaugurated a new way of life by making us the children of God: 'Because henceforth He leads us away from the old to the new way of life, both opening to us the gates on high, and sending down His Spirit from thence to call us to our country there; and not merely to call us, but also with the greatest mark of dignity. For He hath not made us angels and archangels, but He has caused us to become "sons of God" [uíor

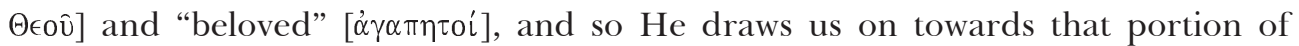
ours' (Chrysostom, 1862c: 206).

As Cyril later would, Chrysostom views the baptism of Christ as a reversal and a restoration from the curse of sin and understands it to be integrally related to 
the incarnation and atonement. Through baptism the subjects of divine wrath become the sons of God. The dominant thrust of both Cyril's and Chrysostom's views on the sacramental benefits obtained by Christ through his baptism are, in the final analysis, parallel with one another and both are deeply linked to their incarnational theology. Cyril observes: 'For he sends in our likeness his own Son who is by nature without alteration or change and not knowing sin in any way, that is by the disobedience of the first we became subject to divine wrath, so through the obedience of the second, we might both escape the curse and the evils from it might come to nought' (1862: 1.882-183). And Chrysostom has Christ say: 'Because I have come to do away the curse that is appointed for the transgression of the law. I must therefore fulfill it all, and having delivered you from its condemnation, in this way to bring it to an end. It is proper for me therefore to fulfill the whole law, by the same rule that it becomes me to do away the curse that is written against you in the law: this being the very purpose of my assuming flesh, and coming here' (1862c: 203).

Cyril's view tends to stress the ontological transformation rooted in Christ's baptism, while Chrysostom underscores the functional and moral requirements to which the incarnate Son subjected himself for the redemption of humanity. Broadly speaking, both developed similar soteriological and sacramental conclusions from their understanding of the baptism of Christ. Through sinful disobedience fallen humanity lost fellowship with God, marring his image and likeness, and leading to corruption and death. Through the incarnation and the life of obedience (even that of baptism and the cross) Christ humbled himself and, as human, fulfilled all the requirements of the law. He reversed the disastrous effects of the corruption of sin and condemnation against humanity, thus conferring the grace of the Holy Spirit, who renews and refashions the believer into a new creation at baptism. Although Chrysostom speaks of other sacramental benefits of baptism, this concept is integral to his understanding of the Christian life.

\section{Heavenly Kinship and the Gift of Adoption}

In Chrysostom's view the conferral of the gift of adoption and the conforming of the Christian to the likeness of Christ are one and the same, and the sacrament of baptism is the means through which this is actualized. To be made a 'son' of God is to be conformed to Christ's likeness and thus be renewed in the image of God. Consequently, to be sacramentally renewed in the divine image is to become by grace what Christ is by nature (Chrysostom, 1862e: 541). The Christian's identification and union with Christ at baptism initiates a new life with its unique privilege: the heavenly kinship of adoption. This spiritual regeneration has implications for the Christian life because a genuine change has occurred (Chrysostom, 1862d: 76). Chrysostom illustrates this regeneration through the use of different metaphors. 
Employing the spiritual birth imagery, Chrysostom distinguishes sharply between the earthly birth according to the flesh and the heavenly birth according to the Spirit, and warns of the eternal consequences for those who have not experienced the latter. The individual who has not been born of water and the Spirit has not yet received the renewal of the divine image, which Chrysostom sometimes refers to as the 'image of sonship' (1862c: 76), or the 'Master's stamp' (1862d: 148), or the 'royal stamp' (1862d: 75). He understands baptism as bringing a radical change in the life of the believer, comparing it with the first creation and contrasting it with the eschatological implications of this spiritual birth. In the beginning man was created after the earth was formed, but the re-creation of humanity happens before this world will be transformed. In the former creation man was made in the 'image of God', but now (at baptism) man is made 'one with God Himself' (1862d: 150). Here Chrysostom emphatically relates the restoration of the divine image in the new creation with divine fellowship, a condition from which sinful humanity had departed and can now be restored through the work of the Spirit at baptism (1862b: 72-73). Adhering to the common practice of catechetical instructions drawn from the creation account of Genesis, he alludes to the events from the primeval prologue in reference to the life sustaining features of water and the work of the Holy Spirit in bringing about this change in the baptized, 'as the womb is to the embryo, so the water is to the believer, since he is formed and shaped in the water' (Chrysostom, 1862d: 153). The sacramental context of baptism is the means of this spiritual birth, for the believer is born of the Spirit and has experienced a new birth in conformity to Christ because the 'image of sonship' has been impressed in this process (Chrysostom, 1862d: 76).

Whereas the catechumen is a stranger and a foreigner, the one who is baptized has a heavenly kinship and has received adoption. The one who is initiated is renewed, changed, and mystically united to the body of Christ. Individual merit cannot earn this gift, as it is solely the work of God through the Holy Spirit (Chrysostom, 1862d: 151). In keeping with the renewal motif, Chrysostom alludes to Pauline terminology from Romans 6, underscoring the distinction between 'the old man' and 'the new man' and noting how the individual identifies with and participates in the mystery of Christ's death, burial, and resurrection:

In it the divine covenant is fulfilled: burial and death, and resurrection and life and all these take place at once. When we immerse our heads in water, just as if in a grave, the old man is buried, and having sunk down, is entirely hidden once for all; then, when we emerge, the new man rises again. Just as it is easy for us to be immersed and to emerge [from the water], so it is easy for God to bury the old man and raise up the new. This is done thrice that you may learn that the power of the Father and of the Son and of the Holy Spirit performs all this (Chrysostom, 1862d: 151).

Through baptism the believer also appropriates the sacramental benefits of the crucifixion, in that not only pardon for sins but also a new quality of life are 
granted (Chrysostom, 1862d: 158). Furthermore, Chrysostom associates the renewal and restoration of the divine image in the baptized with being conformed to the likeness of Christ. Employing Pauline language on matters relating to this discussion, Chrysostom notes that in baptism the old person marred by sin has been buried, and has been raised to new life. In this process we have 'put off' the old and 'put on' the new-Christ himself: 'Baptism is a burial and a resurrection. For the old man is buried with his sin and the new man is resurrected being renewed according to the image of his Creator. We put off the old garment, which has been made filthy with the abundance of our sins; we put on the new one, which is free from every stain. What am I saying? We put on Christ Himself. For all you, says St. Paul, who have been baptized into Christ, have put on Christ' (Chrysostom, 1963: 31.47). Moreover, for Chrysostom, 'to put on Christ' or to be 'clothed with Christ' at baptism is to have Christ indwell the Christian, resulting in the individual's nature being conformed to the nature of Christ, the eternal Son. Elaborating on what this means in his Commentary on Galatians 3:26-27, Chrysostom remarks: "Why did Paul not say: "All you who have been baptized in Christ have been born of God?" For this was the conclusion of the proof that they were sons. But he puts it in a much more awe-inspiring way. For if Christ is the Son of God and you have put on Christ, since you have the Son in yourself, you have become like to Him and you have been brought into one relationship and into one nature with Him' (1862f: 656). Therefore, to receive the gift of adoption at baptism or to be impressed with 'image of sonship' is the same as saying that the Christian has been conformed to the likeness of Christ, and to be conformed to Christ is to be renewed in the image of God.

This is central to Chrysostom's sacramental understanding of baptism. The inner change and renewal of the image of God in the Christian at baptism, to a large extent, underpins Chrysostom's preaching on the Christian life. This thought is echoed in his Baptismal Instructions. In his catechetical homilies, Chrysostom often quotes 2 Corinthians 5:17 ('Therefore, if anyone is in Christ, he is a new creation; the old has gone, the new has come') as a reminder of the gift of transformation that the catechumen has received at baptism (1963: 31.66-78). The soul is purified like a stained statue of gold that has been smelted and refined again; the rust and soot of sin has been removed and the individual has received new life (1963: 31.139). Chrysostom describes various sacramental benefits of baptism, the common theme is that of restoration and renewal wrought through Christ the redeemer, who is the source of grace (1963: 31.57). To be renewed in the image of God, in Chrysostom's view, is to enjoy by grace the privilege of divine fellowship that belongs to the Son by nature. To be conformed to the likeness of Christ is to be restored in the divine image. The conferral of adoption at baptism inaugurates a new way of life, because the Christian by definition is Christ-like.

In keeping with his emphasis on the practical implications of this renewal for the Christian life, Chrysostom observes, 'Do you see how a new creation has truly 
taken place? The grace of God has entered these souls and molded them anew, reformed them, and made them different from what they were' (1963: 31.72). In Chrysostom's thought doctrinal teaching and praxis are intertwined: the evidence of the restoration and renewal of human nature is reflected in the moral and virtuous life of the Christian (1862d: 164). ${ }^{4}$ The starting point for the Christian life is firmly grounded in the restorative ministry of Christ. The consequences of the fall have been overturned, mortality and corruption have been reversed, and through sacramental participation in Christ, humanity can enjoy fellowship with God again. None other than the divine Savior himself actualizes such a restoration in the believer. The Christian life therefore is a reflection of a transformed life in Christ, which is sustained by grace.

\section{Conclusion}

In Chrysostom one sees elements of both Alexandrian and Antiochene traditions. The unitive aspects of his Christology, which are foundational to his soteriological thought, are consistent with the thought of Athanasius and later Alexandrians like Cyril. Given that Cyril was present at Chrysostom's deposition at the Synod of the Oak (where the grounds for his deposition were disciplinary and not doctrinal), and the fact that he eventually restored Chrysostom's name to the liturgical diptychs, one can speculate that it was possible that he might have been acquainted with some of the works of the bishop of Constantinople. The infrastructure of their christological and soteriological thought is parallel at many points.

The focus of Chrysostom's christological picture is on one subject: the LogosSon who partook of flesh and entered brotherhood with us in order to restore our fellowship with God as sons. The reversal of the corruption of sin required God's personal presence in this world for humanity to be redeemed. God had to become human in order that humanity might enjoy divine fellowship. This foundational idea associated mainly with the Alexandrian tradition shapes Chrysostom's picture of Christ. His sacramental thought, which is not far removed from his christological thought, also bears resemblance to the Alexandrian tradition. The inner renewal and the conformation of the baptized to the divine image, and their enjoying the privilege of divine communion through their sacramentally mediated union with Christ, are integral elements of Chrysostom's thought and reflect the participatory nature of his theology.

Chrysostom's hermeneutic methodology is characteristically Antiochene. The literal, historical, and philological aspects of the text are taken account of in the exercise of scriptural interpretation. The biblical text provides both the theological basis for his christological picture and the thematic background for his exegesis. The ethical and moral emphases of Chrysostom's preaching are consistent with Kirche kein Heil? (Korbacher, 1963: 122ff). 
the Antiochene tradition and complement his Christology. The life of Christ is not viewed as a paradigm for moral accomplishment in order to obtain salvation, but is viewed instead as a demonstration of virtue for those who have already been made God's children. One's imitation of Christ ensues from one's participation in Christ and is viewed as a praxeological expression of God's work. This emphasis in Chrysostom's exposition must be associated with the paraenetic goals of his preaching, rather than being explained simply as an Antiochene rhetorical trait.

The role Scripture in the church and the Christian faith as it was enshrined in the Creeds were common motifs shared by the Alexandrians and the Antiochenes. The hermeneutic methodology might have differed superficially, but the approximation of scriptural authority and the core tradition remained the same foundationally. These two branches of the early church shared much in common. Consequently, their status as two opposing or rival schools of thought must not be exaggerated; rather, they should be understood as two traditions within the church that were trying to approximate what they commonly and uniquely maintained was the central message of the Scriptures: Jesus Christ. Chrysostom's Christology can be cited as evidence that these two parallel traditions overlapped, lending support to the view that there was concordance in patristic thought in the fourth and early fifth centuries.

\section{Bibliography}

Cyril of Alexandria (1872) Commentary on the Gospel of John. In Pusey, PE (ed) Sancti patris nostril Cyrilli Archiepiscopi Alexandrini in d. Joannis Evangelium, volume 1. Oxford: Clarendon Press.

John Chrysostom (1862a) Homily on the Baptism and Epiphany of Christ. In Migne, JP (ed) Patrologia Cursus Completus (Series Graeca), volume 49. Paris: Imprimerie Catholique.

John Chrysostom (1862b) Commentary on the Genesis. In Migne, JP (ed) Patrologia Cursus Completus (Series Graeca), volume 53. Paris: Imprimerie Catholique.

John Chrysostom (1862c) Commentary on the Gospel of Matthew. In Migne, JP (ed) Patrologia Cursus Completus (Series Graeca), volume 57. Paris: Imprimerie Catholique.

John Chrysostom (1862d) Commentary on the Gospel of John. In Migne, JP (ed) Patrologia Cursus Completus (Series Graeca), volume 59. Paris: Imprimerie Catholique.

John Chrysostom (1862e) Commentary on Romans. In Migne, JP (ed) Patrologia Cursus Completus (Series Graeca), volume 60. Paris: Imprimerie Catholique.

John Chrysostom (1862f) Commentary on the Galatians. In Migne, JP (ed) Patrologia Cursus Completus (Series Graeca), volume 61. Paris: Imprimerie Catholique. 
John Chrysostom (1957) Commentary on John. In Goggin, TA (trans), The Fathers of the Church, volume 33. Washington, DC: The Catholic University of America Press.

John Chrysostom (1960) Commentary on John. In Goggin, TA (trans), The Fathers of the Church, volume 41. Washington, DC: The Catholic University of America Press.

John Chrysostom (1963) Baptismal Instructions. In Harkins, PW (trans), Ancient Christian Writers, volume 31. New York, NY: Paulist Press.

John Chrysostom (1975) Works. In Schaff, P (ed) A Select Library of the Nicene and Post-Nicene Fathers, volumes 9-14 (First Series). Grand Rapids, MI: William B. Eerdmans.

Korbacher, J (1963) Ausserhalb der Kirche kein Heil? Eine dogmengeschichtliche Untersuchung über Kirche und Kirchenzugehörigkeit bei Johannes Chrysostomus (Münchener Theologische Studien 27). München: Hueber.

Naidu, AJ (2012) Christology and the Christian Life in John Chrysostom (Princeton Theological Monographs). Eugene, OR: Pickwick Publications.

Welch, LJ (1994) Christology and Eucharist in the Early Thought of Cyril of Alexandria. San Francisco, CA: Catholic Scholars Press.

Wilken, RL (1966) Exegesis and the History of Theology: Reflections on the Adam-Christ Typology in Cyril of Alexandria. Church History 35(2): 137-156.

Wilken, RL (1971) Judaism and the Early Christian Mind: A Study of Cyril of Alexandria's Exegesis and Theology. New Haven, CT: Yale University Press. 